\title{
STUDY ON CAUSES AND MANAGEMENT OF PERSISTENT EAR DISCHARGE AFTER MASTOIDECTOMY FOR CHOLESTEATOMA
}

\author{
G. Soundara Rajan ${ }^{1}$, D. Senthamaraikannan², Puthiya Veetil Haridass ${ }^{3}$
}

${ }^{1}$ Assistant Professor, Department of ENT, Chengalpattu Medical College, Chengalpattu.

${ }^{2}$ Assistant Professor, Department of ENT, Chengalpattu Medical College, Chengalpattu.

${ }^{3}$ Associate Professor, Department of ENT, Chengalpattu Medical College, Chengalpattu.

\section{ABSTRACT}

\section{BACKGROUND}

The aim is to study the causes of persistent ear discharge after mastoidectomy for cholesteatoma cases and its management.

\section{MATERIALS AND METHODS}

In this retrospective study over a period of five years (2010-2015) at Chengalpattu Medical College, 50 patients who presented with persistent ear discharge after mastoidectomy for cholesteatoma were included. A detailed history, objective assessment of the cavity, tuning fork test, pure tone audiometry, ear swab for culture and sensitivity and X-ray was taken. An open cavity mastoidectomy with or without tympanoplasty depending upon the cochlear reserve was done.

\section{RESULTS}

Most of the patients were in 20-30 years age group. The mean duration of recurrence of the disease was in the range of 3-5 years in $56 \%$ of patients. Intraoperatively, we noted multiple causative factors in every case. There was no significant difference in healing between adults and children. In $60 \%$ cases dry cavity obtained within 3 months.

\section{CONCLUSION}

Management of residual and recurrent disease consists of proper identification of causative factors in discharging mastoid cavity, meticulous removal of entire disease process, proper removal of buttresses, creation of a small, smooth self-cleaning cavity with wide meatoplasty and temporalis fascia grafting across the middle ear and part of the cavity with ossiculoplasty.

\section{KEYWORDS}

Cholesteatoma, Revision Mastoidectomy, Tympanoplasty.

HOW TO CITE THIS ARTICLE: Rajan GS, Senthamaraikannan D, Haridass PV. Study on causes and management of persistent ear discharge after mastoidectomy for cholesteatoma. J. Evolution Med. Dent. Sci. 2017;6(5):354-357, DOI: 10.14260/Jemds/2017/80

\section{BACKGROUND \\ MATERIALS AND METHODS}

Cholesteatoma is one of the commonest disease that we come across in ENT practice.(1,2) It is considered to be the cause of unsafe ear because of its potential complications. $(3,4,5)$ The primary goal of surgery for cholesteatoma is complete eradication of the disease process. In some patients even after mastoidectomy, they presented with persistent ear discharge. In this study, an attempt has been made to study the causes of persistent ear discharge after mastoidectomy for cholesteatoma cases and its management.

\section{Aims of the study}

1. To evaluate the causes of persistent ear discharge after mastoidectomy for cholesteatoma cases.

2. To treat recurrent and residual disease.

3. To assess the results of revision surgery.

4. To analyse the surgical techniques useful in preventing persistent ear discharge.

Financial or Other, Competing Interest: None.

Submission 23-12-2016, Peer Review 04-01-2017,

Acceptance 07-01-2017, Published 16-01-2017.

Corresponding Author:

Dr. G. Soundara Rajan,

\#No. 4 Tamilmarai Street,

Vandimedu, Villupuram-605602.

E-mail: soundarent@gmail.com

DOI: $10.14260 / \mathrm{jemds} / 2017 / 80$

The present study consists of a series of 50 patients who presented with persistent ear discharge after mastoidectomy for cholesteatoma and who had undergone revision mastoidectomy. Study was conducted over a period of five years.

\section{Inclusion Criteria}

All the patients who had undergone modified radical mastoidectomy for their previous disease for cholesteatoma.

\section{Exclusion Criteria}

Patients who had undergone modified radical mastoidectomy for other previous disease such as granulations.

A detailed history of each patient was recorded. History of previous ear surgery and the year it was performed was also recorded. Most of the patients presented with persistent ear discharge and hard of hearing. Post-operative aural discharge was used as an indicator of cavity disease.

Objective assessment of the cavity and middle ear region was performed under an operative microscope to assess the causative factors. All cases were subjected to tuning fork test and pure tone audiometry was performed to know the cochlear reserve. Air conduction and bone conduction assessment was facilitated by the calculation of pure tone average encompassing the respective air and bone conductions at 500, 1000 and $2000 \mathrm{~Hz}$. This calculation allowed subsequent calculation of an air bone gap. 
Ear swab for culture and sensitivity was taken and proved useful to find out the organisms which secondarily infect cholesteatoma and for post-operative antibiotic cover. All patients were subjected to radiological investigations. The common view used in our institute is the lateral oblique view. This view demonstrates the degree of cellularity, symmetry, cavity, cholesteatoma and anatomical variations. CT scan was done in cases of intracranial involvement and to assess the disease process. Both axial and coronal cuts with $1.5 \mathrm{~mm}$ thick slices are adequate. Frequently when the details of the previous surgical procedure are unknown, CT is of much help. The operative procedure followed in our institute is an open cavity mastoidectomy with or without tympanoplasty depending upon the cochlear reserve. Patients were followed up postoperatively at regular intervals. Post-operative audiometry was done after three months.

\section{RESULTS}

The present study was conducted on 50 patients. Most of the patients were in 20 - 30 years age group (Table 1).

\begin{tabular}{|c|c|c|}
\hline Age Group in Yrs. & No. of Patients & Percentage \\
\hline $10-20$ & 14 & $28 \%$ \\
\hline $20-30$ & 20 & $40 \%$ \\
\hline $30-40$ & 12 & $24 \%$ \\
\hline$>40$ & 4 & $8 \%$ \\
\hline \multicolumn{2}{|c|}{ Table 1. Age Distribution } \\
\hline
\end{tabular}

All patients had recurrence of foul smelling purulent persistent ear discharge with hearing loss. Four patients presented with mixed hearing loss and all other patients had conductive hearing loss (Table 2).

\begin{tabular}{|c|c|c|}
\hline Sl. No. & Presentation & No. of Cases \\
\hline 1. & $\begin{array}{c}\text { Persistent Foul Smelling Scanty } \\
\text { Purulent Ear Discharge }\end{array}$ & All Patients \\
\hline 2. & Hearing Loss & All Patients \\
\hline 3. & Post-Aural Subperiosteal Abscess & 6 \\
\hline 4. & Post-Aural Discharging Sinus & 4 \\
\hline 5. & Aural Polyp & 4 \\
\hline 6. & Facial Nerve Paresis & 2 \\
\hline \multicolumn{3}{|c|}{ Table 2. Types of Presentations } \\
\hline
\end{tabular}

In our study, the mean duration of recurrence of the disease was in the range of 3-5 years in $56 \%$ of patients (Table 3).

\begin{tabular}{|c|c|c|}
\hline Duration of Discharge & No. of Patients & Percentage \\
\hline 1-2 Years & 10 & $20 \%$ \\
\hline $2-3$ Years & 6 & $12 \%$ \\
\hline 3-5 Years & 28 & $56 \%$ \\
\hline >5 Years & 6 & $12 \%$ \\
\hline \multicolumn{2}{|c|}{$\begin{array}{c}\text { Table 3. Duration of Ear Discharge } \\
\text { after Initial Procedure }\end{array}$} \\
\hline
\end{tabular}

While studying the bacterial flora, we found Gramnegative organisms to be the commonest (Table 4).

\begin{tabular}{|c|c|c|}
\hline $\begin{array}{c}\text { Organisms Grown } \\
\text { in Culture }\end{array}$ & $\begin{array}{c}\text { No. of } \\
\text { Patients }\end{array}$ & Percentage \\
\hline Pseudomonas Aeruginosa & 24 & $48 \%$ \\
\hline Proteus Species & 8 & $16 \%$ \\
\hline Pseudomonas and Proteus & 8 & $16 \%$ \\
\hline Pseudomonas and Bacteroides & 4 & $8 \%$ \\
\hline
\end{tabular}

\begin{tabular}{|c|c|c|}
\hline $\begin{array}{c}\text { Pseudomonas and } \\
\text { Staphylococci }\end{array}$ & 4 & $8 \%$ \\
\hline Klebsiella Species & 2 & $4 \%$ \\
\hline \multicolumn{2}{|c|}{ Table 4. Bacterial Flora of Ear Discharge } \\
\hline
\end{tabular}

Intraoperatively, we noted multiple factors in every case. The causative factors seen during surgery are shown in table 5.

\begin{tabular}{|c|c|c|}
\hline Operative Findings & No. of Cases & Percentage \\
\hline Failure of Meatoplasty & 36 & $72 \%$ \\
\hline High Facial Ridge & 28 & $56 \%$ \\
\hline $\begin{array}{c}\text { Incomplete Removal } \\
\text { of Buttresses }\end{array}$ & 12 & $24 \%$ \\
\hline Cortical Bony Overhang & 12 & $24 \%$ \\
\hline Persistence of Outer Attic Wall & 8 & $16 \%$ \\
\hline $\begin{array}{c}\text { Cholesteatoma in Anterior } \\
\text { Epitympanic Recess }\end{array}$ & 12 & $24 \%$ \\
\hline $\begin{array}{c}\text { Cholesteatoma in } \\
\text { Sinus Tympani }\end{array}$ & 16 & $32 \%$ \\
\hline $\begin{array}{c}\text { Incomplete Exenteration } \\
\text { of Tip Cells }\end{array}$ & 4 & $8 \%$ \\
\hline $\begin{array}{c}\text { Incomplete Exenteration } \\
\text { of Sinodural Angle }\end{array}$ & 2 & $4 \%$ \\
\hline $\begin{array}{c}\text { Extensive Disease } \\
\text { in the Antrum }\end{array}$ & 8 & $4 \%$ \\
\hline $\begin{array}{c}\text { Granulation in the Fallopian } \\
\text { Canal at Second Genu }\end{array}$ & 2 & \\
\hline \multicolumn{2}{|c|}{ Table 5. Intraoperative Findings } \\
\hline
\end{tabular}

The operative procedure followed is modified radical mastoidectomy with or without tympanoplasty. There was no significant difference in healing between adults and children. In $60 \%$ cases, dry cavity obtained within 3 months (Table 6).

\begin{tabular}{|c|c|c|}
\hline Results & No. of Cases & $\%$ \\
\hline Dry Cavity in 3 Months & 30 & $60 \%$ \\
\hline $\begin{array}{c}\text { Dry Cavity in 6 Months after } \\
\text { Repeated Removal of Granulations } \\
\text { and Suction Clearance }\end{array}$ & 12 & $24 \%$ \\
\hline $\begin{array}{c}\text { Occasional Scanty } \\
\text { Discharge from the Cavity }\end{array}$ & 8 & $16 \%$ \\
\hline \multicolumn{2}{|c|}{ Table 6. Results of Revision Mastoidectomy } \\
\hline
\end{tabular}

Post-operative audiogram is done after 3 months in cases where the patient had ossicular reconstruction (table 7).

\begin{tabular}{|c|c|c|c|}
\hline $\begin{array}{c}\text { Sl. } \\
\text { No. }\end{array}$ & $\begin{array}{c}\text { Hearing } \\
\text { Results }\end{array}$ & $\begin{array}{c}\text { No. of } \\
\text { Cases }\end{array}$ & Percentage \\
\hline 1. & A - B Gap Closure & Nil & $0 \%$ \\
\hline 2. & 20 dB A - B Gap & Nil & $0 \%$ \\
\hline 3. & 30dB A - B Gap \& Above & 24 & $48 \%$ \\
\hline 4. & No Improvement & 20 & $40 \%$ \\
\hline 5. & $\begin{array}{c}\text { Worse than } \\
\text { Preoperative Level }\end{array}$ & 6 & $12 \%$ \\
\hline \multicolumn{3}{|c|}{ Table 7. Hearing Results } \\
\hline
\end{tabular}

\section{DISCUSSION}

The aim of otologic surgery for chronic otitis media is to make the ear safe and to preserve or restore the hearing. Surgical procedure is done depending upon the extent of disease, priority of the patient and surgical expertise available. $(6,7,8)$ Totally $40 \%$ of patients attending ENT OPD 
had otorrhoea. Among them, $30 \%$ patients had cholesteatoma and underwent mastoidectomy. Out of these patients, 30\% had persistent otorrhoea after mastoidectomy. For 50 study patients of persistent ear discharge after mastoidectomy, revision mastoidectomy was done.

In our study, the mean duration of recurrence of the disease was in the range of 3-5 years in 56\% of patients. According to Simon C. Parisier \& Mathew B Hanson, ${ }^{9}$ generally residual cholesteatoma develop within 36 months after the initial procedure. Recurrent cholesteatoma may develop long after the initial surgery. So it is difficult in reporting the rates of recurrent or residual cholesteatoma. 10

While studying the bacterial flora, in the present series, we found Gram-negative organisms to be the commonest. Pseudomonas- 48\%, Proteus- 16\%, Pseudomonas and Proteus- $16 \%$ were the organisms mostly cultured. Bacteriological study by Ojala, revealed no significant difference between the preoperative $\&$ postoperative state regarding the types \& specificity of organisms. ${ }^{11}$

In our study, a combination of multiple causative factors were seen in every case as shown in Table 5. Similarly, Mahadeviah and Nadol ${ }^{12}$ also showed that a combination of multiple factors in every case of discharging mastoid cavity. The important factors contributing to failure of primary surgery are suppuration in the mastoid cavity, may be due to residual disease in the tip, along the facial ridge, zygomatic cells, sinodural angle and cholesteatoma in regions easily overlooked during surgery such as sinus tympani, facial recess and anterior epitympanic recess. $(9,13,14,15,16,17,18,19)$ The major sites of residual/recurrent disease contributing to discharging cavities at the time of revision mastoid surgery in our series were failure of meatoplasty and high facial ridge. The attic region which was the second most common site of residual cholesteatoma in our series, disease was found in anterior epitympanum anterior to head of malleus in patients having intact malleus and removal of malleus head was mandatory to remove the disease from this area. In others the bony over hang was the main reason of persistence of disease in this area. In $32 \%$ of patients with residual cholesteatoma in mesotympanum the sinus tympani and stapes were culprit areas. Perisinus/sinodural angle and mastoid tip cells should be given special attention to adequately exteriorise the mastoid air cells. $(15,20)$

The cholesteatoma was lying deep in sinus tympani in these cases which could only be viewed by angled telescope and removal of stapes suprastructure was necessary to eradicate the disease from this area. Thus, we agree with Ajalloueyan $\mathrm{M}$ et.al ${ }^{7}$ and El-Meselaty $\mathrm{k}$ et.al ${ }^{21}$ that usage of otoendoscope in cholesteatoma surgery is important as it will help to reduce the incidence of residual disease in mastoid surgery. The principle of creating a dry and self-cleaning mastoid cavity involves extensive surgery. The size of a large cavity can be reduced by amputation of the mastoid tip and drilling it to level of EAC. Rounding of the cavity edges over the tegmen, sinodural angle and sigmoid sinus along with saucerisation of the cavity helps in reducing the size of the cavity by prolapse of surrounding soft tissue within the cavity. New techniques of mastoid obliteration are also used with good results. $(22,23,24)$ Decreasing the size of the cavity not only is important for healing but also decreases the need for post-operative cavity care. Narrow meatus is one of the common reasons of failure in CWD mastoidectomy $(12,14,15,16,18)$ thus an enlarged meatus is an essential integral part of the
CWD procedure and failure to perform an adequate meatoplasty may fail even in the most perfectly performed CWD procedures. Adequate meatoplasty opening is necessary to provide adequate surface volume ratio for aeration, epithelial stability and good post-operative visualisation. The final appearance of the meatus should be cosmetically acceptable to the patients. Wide meatoplasty decreases the incidence of stenosis of canal after surgery as none of our patients had canal stenosis after 5 years of followup.

50 cases were followed regularly up to two years. Dry cavity was obtained in 30 patients within 3 months of postoperative period. In 12 patients, dry cavity occurred during the period of 6 months after repeated removal of granulation tissue and suction clearance under an operating microscope. Eight patients had persistent scanty, occasional ear discharge. These results correlate with the study by Katewad. 25

The postoperative audiogram was done after 3 months and yearly; during the followup period hearing results were fairly accepted in $48 \%$ of the patients. In $40 \%$ patients, there is no improvement of hearing seen, in $12 \%$ hearing worsened. The above results were comparable with various studies. $(9,26)$

The results of healing in our cases with revision surgery and meatoplasty are consistent with Mills ${ }^{27}$ where he stated that cavity revision above is likely to result in a dry ear in $57 \%$ of cases and while the combination of this approach with wide meatoplasty increases the success rate to $83 \%$. According to Bhatia et al ${ }^{14}$ and Tekin et al, ${ }^{28}$ cavities are more likely to be dry, if they are not excessively large, having a low facial ridge, an adequate meatal opening and a closed middle ear space.

\section{CONCLUSION}

A combination of multiple factors was responsible in every case of persistent ear discharge after mastoidectomy. Of these, failure of meatoplasty $(72 \%)$ and high facial ridge (56\%) accounted for most of the cases. Management of residual and recurrent disease consists of proper identification of causative factors in discharging mastoid cavity, meticulous removal of entire disease process, proper removal of buttresses, creation of a small, smooth selfcleaning cavity with wide meatoplasty and temporalis fascia grafting across the middle ear and part of the cavity with ossiculoplasty.

\section{REFERENCES}

[1] Westerberg BD, Lee PK, Lukwago L, et al. Crosssectional survey of hearing impairment and ear disease in Uganda. J Otolaryngol Head Neck Surg 2008;37(6):753-8.

[2] Akinpelu OV, Amusa YB, Komolafe EO, et al. Challenges in management of chronic suppurative otitis media in a developing country. J Laryngol Otol 2008;122(1):1620.

[3] Mostafa BE, El Fiky LM, El Sharnouby MM. Complications of suppurative otitis media: still a problem in the 21st century. ORL J Otolaryngol Relat Spec 2009;71(2):87-92.

[4] Dubey SP, Larawin V. Complications of chronic suppurative otitis media and their management. Larygoscope 2007;117(2):264-7. 
[5] Smith JA, Danner CJ. Complications of chronic otitis media and cholesteatoma. Otolaryngol Clin North Am 2006;39(6):1237-55.

[6] Toner JG, Smyth GD. Surgical treatment of cholesteatoma: a comparison of three technique. Am J Otol 1990;11(4):247-9.

[7] Ajalloueyan M. Experience with surgical management of cholesteatomas. Arch Otolaryngol Head Neck Surg 2006;132(9):931-3.

[8] Shirazi MA, Muzaffar K, Leonetti JP, et al. Surgical treatment of pediatric cholesteatomas. Laryngoscope 2006;116 (9):1603-7.

[9] Weiss MH, Perisier SC, Han JC, et al. Surgery for recurrent and residual cholesteatoma. Laryngoscope 1992;102(2):145-51.

[10] Stangerup SE, Drozdziewicz D, Tos M, et al. Recurrence of attic cholesteatoma: different methods of estimating recurrence rates. Otolaryngol Head Neck Surg 2000;123(3):283-7.

[11] Ojala JK, Sorri M, Sipila A. Comparison of preoperative and postoperative bacteriology of chronic ears. Journal of Laryngology, Otology 1992;95:1.

[12] Nadol JB. Revision mastoidectomy. Otolaryngol Clin North Am 2006;39(4):723-40, vi-vii.

[13] Veldman JE, Braunius WW. Revision surgery for chronic otitis media: a learning experience. Report on 389 cases with a long-term follow-up. Ann Otol Rhinol Laryngol 1998;107(6):486-91.

[14] Sanjaya B, Karmarkar S, DeDonato G, et al. Canal wall down mastoidectomy: causes of failure, pitfalls and their management. The journal of laryngology and otology 1995;109(7):583-9.

[15] Bercin S, Kutluhan A, Bozdemir K, et al. Results of revision mastoidectomy. Acta Otolaryngol 2009;129(2):138-41.

[16] Gorur K, Ozcan C, Unal M, et al. Causes of failure in open cavity mastoidectomy. Kulak Burun Bogaz Ihtis Derg 2002;9(3):179-83.
[17] Pillsbury HC, Carrasco VN. Revision mastoidectomy Arch Otolaryngol Head Neck Surg 1990;116(9):101922.

[18] Phelan E, Harney M, Burns H. Intraoperative findings in revision canal wall down mastoidectomy. Ir Med J 2008;101(1):14.

[19] Faramarazi A, Motasaddi-Zarandy M, Khorsandi MT. Intraoperative findings in revision chronic otitis media surgery. Arch Iran Med 2008;11(2):196-9.

[20] Cho YS, Hong SD, Chung KW, et al. Revision surgery for chronic otitis media: characteristics and outcomes in comparison with primary surgery. Auris Nasus Larynx 2010;37(1):18-22.

[21] El-Meselaty K, Badr-El-Dine M, Mandour M, et al. Endoscope affects decision making in cholesteatoma surgery. Otolaryngol Head Neck Surg 2003;129(5):490-6.

[22] Yung M, Tassone P, Moumoulidis I, et al. Surgical management of troublesome mastoid cavities. J Laryngol Otol 2011;125(3):221-6.

[23] Gopalakrishnan S, Chandha SK, Gopalan G, et al. Role of mastoid obliteration in patient with persistent cavity problems following modified radical mastoidectomy. J Laryngol Otol 2001;115(12):967-72.

[24] Magliulo G, D’Amico R, Fusconi M. Reconstruction of old radical cavities and long-term results. J Otolaryngol 2004;33(3):155-9.

[25] Katewad SKS, Avuluri RK, Maimal MK. Revision mastoidectomy and its goal. J Evid Based Med Health care 2016;3(50):2540-3.

[26] Sheehy JL. Recurrent and residual disease in cholesteatoma surgery. Clin Otolaryngol 1978;3(4):393-403.

[27] Mills RP. Surgical management of the discharging mastoid surgery. Journal of Laryngology \& Otology 1992;16:1-6.

[28] Tekin M, Osma U, Meric F, et al. Clinical assessment of patients with chronic otitis media with cholesteatoma. Kulak Burun Bogaz Ihtis Derg 2002;9(4):263-6. 